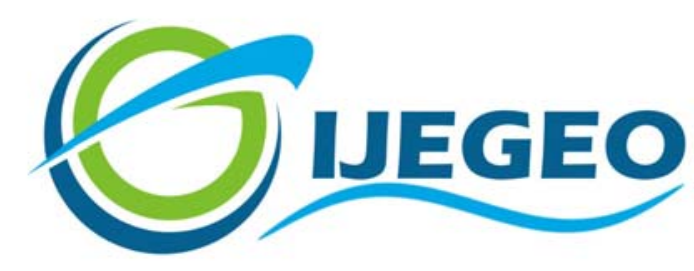

International Journal of Environment and Geoinformatics (IJEGEO) is an international, multidisciplinary, peer reviewed, open access journal.

\title{
GIS Based Appraisal of Waste Disposal for Environmental Assessment and Management in Mainland Area of Lagos State, NG
}

\section{Rafiu Jimoh, Vivian Chuma, Adeniji Moradeyo, Ogungbade Olubukola, S.O.Sedara, Afonja Yusuf \& A.A.Jimoh}

\section{Chief in Editor}

Prof. Dr. Cem Gazioğlu

\section{Co-Editor}

Prof. Dr. Dursun Zafer Şeker, Prof. Dr. Şinasi Kaya, Prof. Dr. Ayşegül Tanık and Assist. Prof. Dr. Volkan Demir

Editorial Committee (2019)

Assos. Prof. Dr. Abdullah Aksu (TR), Prof. Dr. Bedri Alpar (TR), Prof. Dr. Lale Balas (TR), Prof. Dr. Levent Bat (TR), Prof. Dr. Paul Bates (UK), Prof. Dr. Bülent Bayram (TR), Prof. Dr. Luis M. Botana (ES), Prof. Dr. Nuray Çağlar (TR), Prof. Dr. Sukanta Dash (IN), Dr. Soofia T. Elias (UK), Prof. Dr. A. Evren Erginal (TR), Assoc. Prof. Dr. Cüneyt Erenoğlu (TR), Dr. Dieter Fritsch (DE), Assos. Prof. Dr. Çiğdem Göksel (TR), Prof.Dr. Lena Halounova (CZ), Dr. Hakan Kaya (TR), Assoc. Prof. Dr. Maged Marghany (MY), Prof. Dr. Michael Meadows (ZA), Prof. Dr. Nebiye Musaoğlu (TR), Prof. Dr. Erhan Mutlu (TR), Prof. Dr. Masafumi Nakagawa (JP), Prof. Dr. Hasan Özdemir (TR), Prof.Dr. Chryssy Potsiou (GR), Prof. Dr. Erol Sarı (TR), Prof. Dr. Maria Paradiso (IT), Prof. Dr. Petros Patias (GR), Prof. Dr. Elif Sertel (TR), Prof. Dr. Nüket Sivri (TR), Assoc. Prof. Dr. Füsun Balık Şanlı (TR), Prof. Dr. Uğur Şanlı (TR), Assoc. Prof. Dr. Oral Yağcı (US), Prof. Dr. Seyfettin Taş (TR), Assoc. Prof. Dr. Ömer Suat Taşkıın (TR), Dr. İnese Varna (LV), Dr. Petra Visser (NL), Prof. Dr. Selma Ünlü (TR), Assoc. Prof. Dr. İ. Noyan Yilmaz (AU), Prof. Dr. Murat Yakar (TR), Assit. Prof. Dr. Sibel Zeki (TR) 


\title{
GIS Based Appraisal of Waste Disposal for Environmental Assessment and Management in Mainland Area of Lagos State, NG
}

\author{
Rafiu Jimoh $^{*, 1}$, (D) Vivian Chuma², Adeniji Moradeyo ${ }^{3}$, Ogungbade Olubukola ${ }^{4}$, S.O.Sedara ${ }^{5}$, \\ Afonja Yusuf ${ }^{6}$, A.A.Jimoh ${ }^{7}$
}

${ }^{1}$ Geomodeling and Geoexplore Consultants Limited, P.O.BOX 302, Ikorodu, Lagos State, NG

2Department of Hospitality and Tourism Management, Federal University Wukari, Taraba State, NG

${ }^{3}$ Department of Physics, Federal University of Agriculture, Abeokuta, NG

${ }^{4}$ Department of Earth Sciences, Olabisi Onabanjo University, Ago Iwoye, Ogun State, NG

${ }^{5}$ Department of Physics and Electronics, Adekunle Ajasin University, Ondo State, NG

${ }^{6}$ Department of Surveying and Geoinformatics, Federal School of Surveying, P.M.B 1024, Oyo, Oyo State,

NG ${ }^{7}$ Department of Quantity Surveying, The Oke-Ogun Polytechnic,Saki,Oyo State, NG.

Corresponding Author*

Received 30 Oct 2018

E-mail: geomodgeoexploreconsultants@gmail.com

Accepted 28 March 2019

How to cite: Jimoh et al., (2019). GIS Based Appraisal of Waste Disposal for Environmental Assessment and Management in Mainland Area of Lagos State, Nigeria, International Journal of Environment and Geoinformatics (IJEGEO), 6(1): 76-82. DOI: 10.30897/ijegeo.476449

\begin{abstract}
An appraisal of Waste disposal for environmental assessment and management in Lagos Mainland of Lagos state using the GIS has been carried out. GIS has been a veritable tool for analyzing, storing, querying, capturing, displaying and managing of Geographic information or data. This paper addressed the usefulness of Geographic information system applications in Waste disposal distribution and in management. The coordinates of the existing waste dump were collected through field survey and a Garmin 78Sc hand held Global positioning system (GPS) receiver was used in the coordinate acquisition. The result of the field observations and analysis showed that the GIS can be used to efficiently monitor waste disposal location, Scheduling of Waste-Bin and this can invariably be used for proper planning in environmental sanitation, assessment and management holistically. This study shows that the use of Geographic Information system cannot be overemphasized in the spatial mapping of solid waste disposal for environmental management and sanitation assessment.
\end{abstract}

Keywords: GIS, Spatial Mapping, GPS, Waste Disposal, Lagos Mainland.

\section{Introduction}

As poverty, population growth, and high urbanization rates combined with ineffectual and under funded governments to prevent efficient management of wastes (UNDP, 2004); municipal solid waste disposal has been enormous concern in developing countries (Mohammedshum et al., 2014. Geographic Information Systems (GIS) is a relatively young field, with antecedents that is dated back to hundreds of years in the fields of cartography and mapping. Today, GIS provides a digital way for storing, retrieving, manipulating, analysing, and displaying geographically referenced data. Since GIS has the potential of including ecological, biological, demographic, or economic information, it becomes a valuable tool in the environmental and engineering sciences (Goodchild et al, 1999). Over the past five decades or so years, urbanisation - that is the proportional change between the population living in rural areas and that living in urban areas - has become one of the most important trends in human settlements development (Kironde, 2000; Yomralıoğlu, 2000; Direk et al, 2012; Şeker et al., 2013; Goumehei et al., 2016). GIS is among Management Information Systems and part of the Geo information technology adopted in solid waste management in many countries. Experiences may be obtained from developed countries such as the USA, France, Britain, etc. and other developing countries such as Mexico, China, Ghana, South Africa, Kenya, Nigeria; etc. The most common problems associated with improper management of solid waste include diseases transmission, fire hazards, odour nuisance, atmospheric and water pollution, aesthetic nuisance and economic losses (Basağaoğlu, et al., 2007; Gürel et al., 2007). A Disposal site must consider all the socio-economic, environmental and land use factors within the city as well as people safety. Waste disposing is an important part of waste management system, which requires much attention to avoid environmental pollution. The scientific and systemic management of Municipal Solid Waste involves processing of the significant amount of the spatial data, acceptable criteria's and regulations with efficient correlation between them. For proper decision, all inputs have to be considered together at once and correlated. As the complexity of the management increases, there is requirement of computerized software to do the analysis. In recent years, Geographical Information System (GIS) has emerged as a very important tool for decision making in management practices of solid waste. Geographical Information System (GIS), software are capable of handling spatial data along with non-spatial attributes. The effectiveness of solid waste disposal depends upon the selection of proper site and current global trend of waste management problems stems from unsustainable methods of waste disposal, which is ultimately a result of 
inadequate planning (Abbas et al., 2011; Baykal, et al., 2003; Menegho, 2019). The prevailing situation of dumping of wastes without proper inspection and separation leads to environmental pollution causing a tremendous growth in health-related problems. "Domestic, industrial and other wastes, either of low or medium level causes environmental pollution perennially for mankind." (Senthil, 2002). Solid Waste disposal and Management is an integral part of the public health and environmental control. Solid waste generated right from the beginning of humanity, earlier societies mostly are natural and food waste. Problems were little earlier, however, with rapid urbanization, growth in urban population, and development of technologies -e.g. packaging-, the problems of solid waste become more complex as more and more solid waste is generated. With the passage of time and continuous urbanization as well as increase in population the situation, get more and more critical. Recently, there has been an increase in research that uses Geographic Information System (GIS) application as a tool for Municipal Solid Waste management estimation and planning. Municipal Solid Waste management practices require collection of decisive information, which is for taking corrective measures as well as for proper planning to ensure sustainability (Ramachandra and Saira, 2003). Waste management in GIS assistance provides a wide range of opportunities at all stages, from the time the waste is reached to the final destination, or at a stage where it does not further threaten the environment. Studies such as Chang et al. (2007), Sharholy et al. (2007), Wilson \& Vincent (2008), Sumathi et al. (2008), Rahman \& Rahman (2009), Nishanth et al. (2010), Khajuria et al. (2011); Mohammedshum et al. (2014), Rafiu et al., (2018); Allouche et al., (2018) described the role of GIS in solid waste management. Due to the rapid expansion of population and urbanization, it is badly needed to develop controlled solid waste dumping site to prevent contamination problems through illegal dumping of refuse. Therefore, this study aimed at creating a spatially distributed disposal sites, which features waste generation, location of waste bins, type and amount of waste generate in a particular area. The study also proposes the potential waste disposal sites using GIS technique for better Municipal Waste management in the Lagos Mainland area of Lagos State.

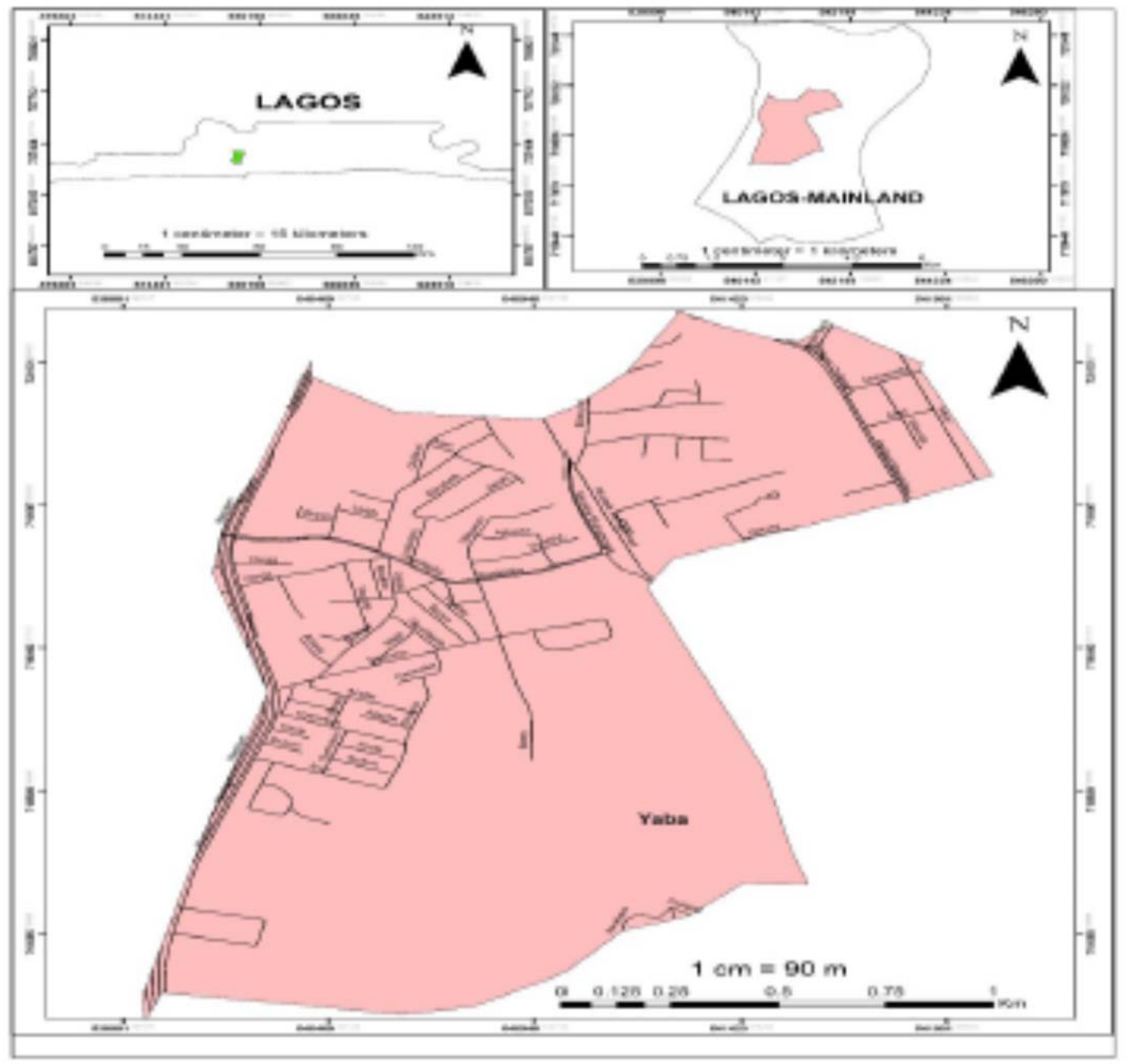

Figure 1: Map showing the study area(Lagos Mainland) 


\section{Study Area}

The study area is Lagos mainland in the heart of Lagos metropolis, which geographically falls within coordinates of $6050^{\prime} 84^{\prime} ' \mathrm{~N}$ and $30.38^{\prime} 42^{\prime}{ }^{\prime} \mathrm{E}$ as seen in fig 1. There are several Federal Government Institutions in the area, which include Queen's College, the Nigerian Institute of Medical Research, the Yaba College of Technology, Igbobi College, the University of Lagos, the Federal Science and Technical College, and the Federal College of Education. In Yaba community and most local areas in Nigeria, wastes are mostly burnt or dumped in open spaces, usually infringing on the right of ways of infrastructures such as roads, market places, undeveloped plots of land, neighborhood of residential buildings. This can be confirmed from the sight of the spatial pattern of waste dumpsites captured within the study area as shown in the fig 2 .

\section{Methodology}

The methodology involved acquisition of spatial and attribute data using the coordinates of the existing waste dump acquired by field survey and a Garmin 78Sc hand helded Global positioning system (GPS) receiver, Ikonos satellite imagery $4 \mathrm{~m}$ resolution of Lagos Mainland area of Lagos State covering the entire Yaba LCDA and a Base Map of Lagos Mainland Local Government showing the road networks. The image was georeferenced and digitized showing the location of existing waste disposal points. ArcGIS 10.3 software was used to create a database and shape files were also created and on-screen digitization was done. The study adopt field survey and survey research design for the acquisition of spatial and non-spatial data accordingly. Snapshots of some waste locations were taken.

\section{Sources of Data}

The sources of data and type of data used for this study involved Ikonos satellite imagery of $4 \mathrm{~m}$ resolution from RECTAS, Coordinate data from the Garmin 78Sc GPS receiver, which was acquired during the field survey, field survey questionnaire from the field survey carried out.

Table 1: Sources of Data and Data used

\begin{tabular}{|c|c|c|c|}
\hline Data Acquisition & Data Type & Data & Source \\
\hline $\begin{array}{lll}\begin{array}{l}\text { Coordinates } \\
\text { disposal site }\end{array} & \text { of } & \text { Waste } \\
\end{array}$ & Primary & $\begin{array}{l}\text { Coordinates generated } \\
\text { from the disposal site }\end{array}$ & Field Survey by GPS \\
\hline $\begin{array}{l}\text { Administered } \\
\text { questionnaire }\end{array}$ & Primary & $\begin{array}{lll}\begin{array}{l}\text { Respondent } \\
\text { analysis }\end{array} & \text { data } & \text { for } \\
\end{array}$ & Field Survey \\
\hline IKONOS multispectral & Secondary & Satellite Imagery & RECTAS \\
\hline
\end{tabular}

\section{Waste Dumpsites Identification}

The issue of waste is not only because of increase quantities but also largely because of inadequate management system (E. Tinmaz and I. Demir, 2005) Open dumps cause threat to the public as well as to the environment. Geographic Information Systems (GIS) are increasingly being recognized for their use in storing and analysing the large volumes of data necessary for managing the environment. To attain the study objective, the data needed to perform is the $\mathrm{X}$ and $\mathrm{Y}$ coordinates of the existing waste dumpsites. The coordinates of the existing waste dump were collected through field measurement/ field survey method. Garmin 78Sc handheld GPS receiver was used to obtain the coordinates. The coordinates of the existing solid waste dumpsites collected during fieldwork were imported into the ArcGIS 10.3 as a text file then converted to shapefile to show the location of the dumpsites. The points were superimposed on the street map.

\section{Management, Assessment and Scheduling of Waste disposal Location}

The field observations concern characteristics of dumpsites and general environmental sanitation. The field observations were based on a checklist in relation to such items as spatial extent of dumpsites, location and stage of decomposition of materials. It also consists of interview with some of the dumpsite attendants and close-by residents. From the seventy (70) samples, sixty (60) respondents completed their questionnaire and were subsequently analysed. However, the sixty (60) samples were subsequently used for the study. Seventy Nine (79) Coordinate points were obtained during the site survey, which were the waste disposal points. The results from the questionnaire done for the public shows that virtually about $85.7 \%$ of residents keep their waste in a polythene bags or household waste been and later dump the waste indiscriminately in an open uncovered places near the road, while $14.4 \%$ dump the waste directly in waste bin provided by the local government and most of residents tend to keep their waste for two to three days at their places.

\section{Applications of GIS in waste disposal management}

Solid waste management comprises several phases, starting from the stage where the waste is generated until it reaches its final destination or at a stage where it is no more a threat to the environment. It is observed that solid waste management can be bifurcated into mainly two Phases. One is the waste management in the area where it is generated and second is the management of waste at dumping grounds." (Moiz Ahmed Shaikh, 2006). The development of Geographic Information System (GIS) and its use throughout the world has contributed a lot in improving waste management systems. GIS helps to manipulate data in the computer to simulate alternatives 
and to take the most effective decisions. GIS can add value to waste management applications by providing outputs for decision support and analysis in a wide spectrum of projects such as route planning for waste collection, site selection exercises for transfer stations, landfills or waste collection points. GIS provides a flexible platform which integrates and analyses maps and waste management databases. GIS has very distinguishing and powerful functions that play an important role in decision- making and planning process. "The most distinguishing parts of a GIS are its functions for spatial analysis, i.e. operations that use spatial data to derive new geo- information. Spatial queries and process models play an important role in satisfying user needs. GIS allows us to create and store as many layers of data or maps as we want and provides various possibilities to integrate tremendous amounts of data and map overlays into a single output to aid in decision-making (Chang et al. 1997).

The changing production and consumption patterns have caused a rise in the volume of solid waste putting considerable pressure on Governments in dealing with the increased waste generation. It implies that local authorities will require huge capital investments and Operational strategies for collection, transportation and disposal of solid waste. Delimiting factors such as limited financial resources have made it imperative to replace existing ad hoc methods employed in solid waste management and planning (Vijay et al. 2008). Sarptas et al. (2005) studied the use GIS in solid waste management in coastal areas as a decision support system with a case study on landfill site selection. The results of the study are that GIS is becoming a powerful tool in Solid Waste Management. However, there are still some drawbacks and deficiencies in applying the method extensively. For example, it is not applied in solid waste generation studies because large fluctuations in solid waste generation by time and space and the dynamic nature of urban areas generate several difficulties in determining the current solid waste generation patterns. In the early period of GIS technology, from the 1980's to the early 1990's, GIS software was capable of executing only basic geographical operations. These Capabilities of GIS software limited the user to only basic tasks such as exclusion and allowed them to determine only alternative landfill sites in landfill siting applications. Advances in information technology and increasing access to computer systems by decision makers have improved the usefulness of computer models and computer aided technologies in decision support system in the last decade.

One of the typical examples is the Solid Waste Management systems. The GIS models do not only support the decision procedure but also facilitate the communication and mutual understanding between decision maker and the people, because the implications of a Solid Waste Management closely affect the society. However, the basic limitations in the use of GIS in Solid Waste Management are the data availability. Because, especially in developing countries the available data are very scarce and access to the data is very poor and tiring. In addition, the existing data are not reliable, not collected, stored and disseminated systematically. More comprehensive researches and more efforts on data gathering to fulfil the needs of GIS models are recommended. Since routing models make extensive use of spatial data, GIS can provide effective handling, displaying and manipulation of such geographical and spatial information. For example, Ghose et al, 2006 proposed a model for the system of Municipal Solid Waste collection that provides planning for distribution of collection bins, load balancing of vehicles and generation of optimal routing based on GIS. Moiz, A. S, 2006, enumerated that GIS support a formal process of optimum location of community waste bins based on buffer electronic maps. The process enables an analyst to consider a variety of geographic factors essential for the planned facility and others merely desirable. However, GIS is an appealing strategy for an agency seeking a rational unbiased location for a local facility such as an incinerator or dumpsite.

\section{Results and Discussion}

For an effective environmental management and assessment for decision support system in the Lagos mainland area of Lagos Metropolis, the waste disposal sites has been assessed, evaluated and the spatial distribution of the waste disposal points and coordinates of the sites known as seen in fig 2 respectively. This has proved very useful in the assessment and management of Waste disposal sites. During the field survey, the dumpsites are relatively along the road. These waste dump site are located indiscriminately without considering factors such as centrality, adequacy of space, other neighboring land-uses, etc. with the GPS Location of the waste dump site and the existing road network of the Mainland.

\section{Field Analysis of Wastes Schedule}

To determine the quantities of wastes emanating from each waste bin the result of daily solid waste generated per household was considered and average solid waste generated per person per household and the schedule for the days of waste collection. This schedule is very vital as it indicates areas of daily need in deploying personnel and evacuating solid wastes from neighborhoods knowing the locations in the database. The calculations are shown below:

A. The amount of daily waste generated per each household computed were arrived at by applying formula:

DailyW.G / Household=summation of each house hold weighted waste sampled / No.of days weighed

Summation of daily waste generated by all households sampled $=630.51 \mathrm{~kg}$

B. The average daily waste generated per person was computed as below

Summation of daily waste generated by all households sampled $=464.2 \mathrm{~kg}$ 
Summation of the population size of all household sampled $=571$ persons

AveragedailyW.G/person=Summation daily waste generated by all households sampled

Summation of population size of all household sampled

Average daily W.G /person $=464.2 \mathrm{~kg} / \quad 571=$ $0.81 \mathrm{~kg} /$ day $/$ person

C. The day of waste collection from each household was computed, using the different size of waste bin, for some of the households sampled:

Day of waste collection per household=size of bin average waste generated / house
For Example, the day of waste collection from house A1 is $=100 / 6.5=15$

This means that the waste of household A1 is due for collection at the interval of 15 days.

From the figure 3 above, the diagram represents a conceptual model for solid waste collection system and in order to make GIS a veritable tools in solid waste collection system application, a number of tools are needed which are sensitive to management of the process. This includes resources, organisation, information and coordination. Invariably GIS would become essential and powerful veritable tools in solid waste collection if all the aforementioned items are in place.

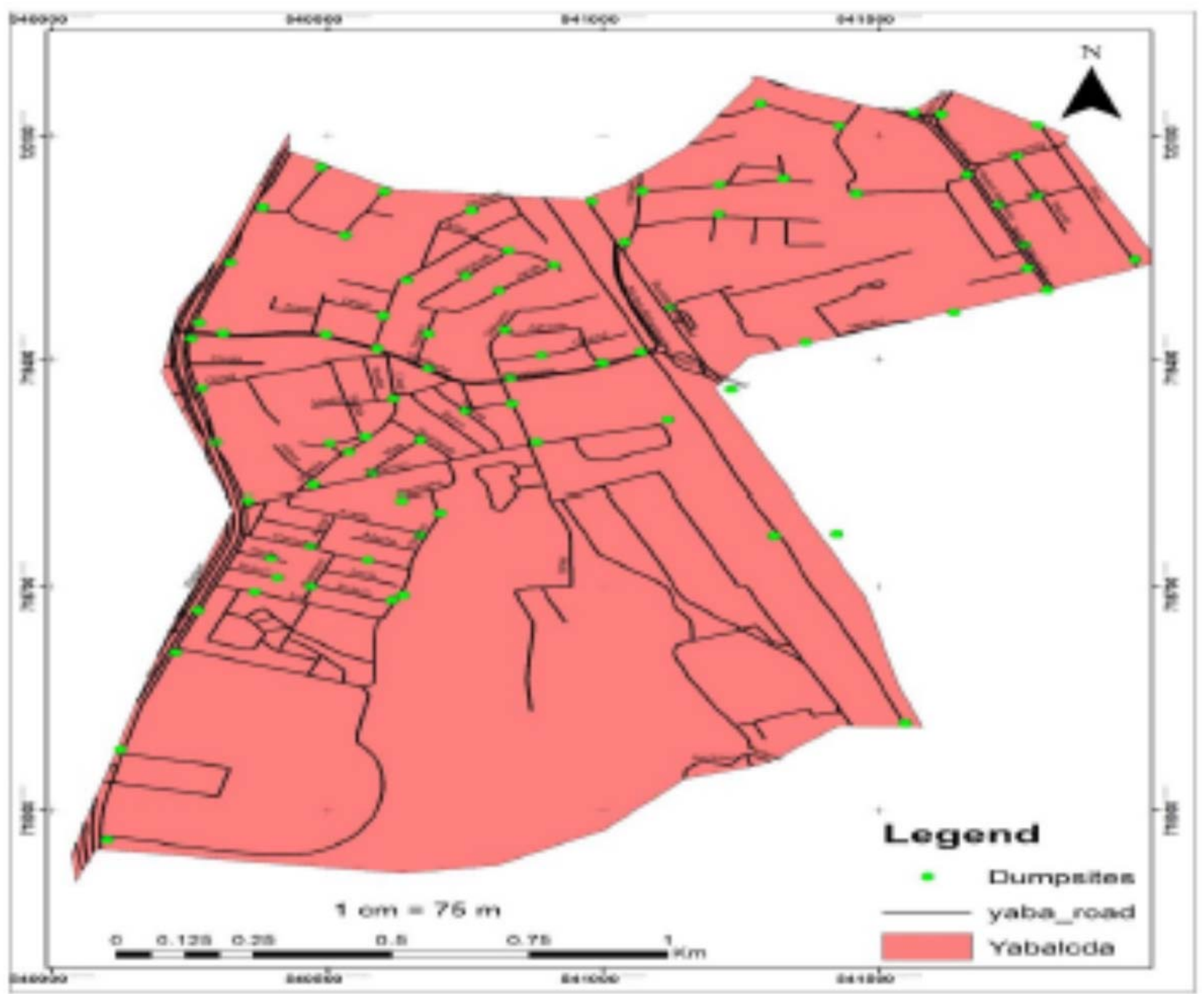

Figure 2: Spatial distribution of the waste dumpsite in Lagos Mainland

\section{Conclusion}

The Application of Geographic Information System (GIS) to appraise waste disposal in Lagos Mainland of Lagos State, Nigeria has been possible for environmental assessment and management. Therefore, in order to showcased an efficient and effective waste management system, GIS has be adopted because of it capability in handling both spatial and non-spatial data necessary for effective waste disposal and collection system. The study presents the type and condition of the waste disposal units in Lagos Mainland Area with at least 79 waste disposal units. Analysis can be made from the results of query/buffering operations conducted, which will enhance decision making by government, and those interested in solid waste management. The database system allows easy access to the condition of waste disposal units, type, and the location of the waste disposal units, storage and updating of the database in the nearest future. 
Nowadays, with the rapid population increasing, the urbanization process is accelerating and it is seen that the amount of waste in social consumption is increased as a natural result. In order to solve the environmental problems that arise in this context, regular storage, which is one of solid waste disposal methods, is preferred.
However, the most appropriate location for this purpose is a complex and difficult positional problem for decision makers. Waste management in GIS assistance provides a wide range of opportunities at all stages, from the time the waste is reached to the final destination, or at a stage where it does not further threatens the environment.

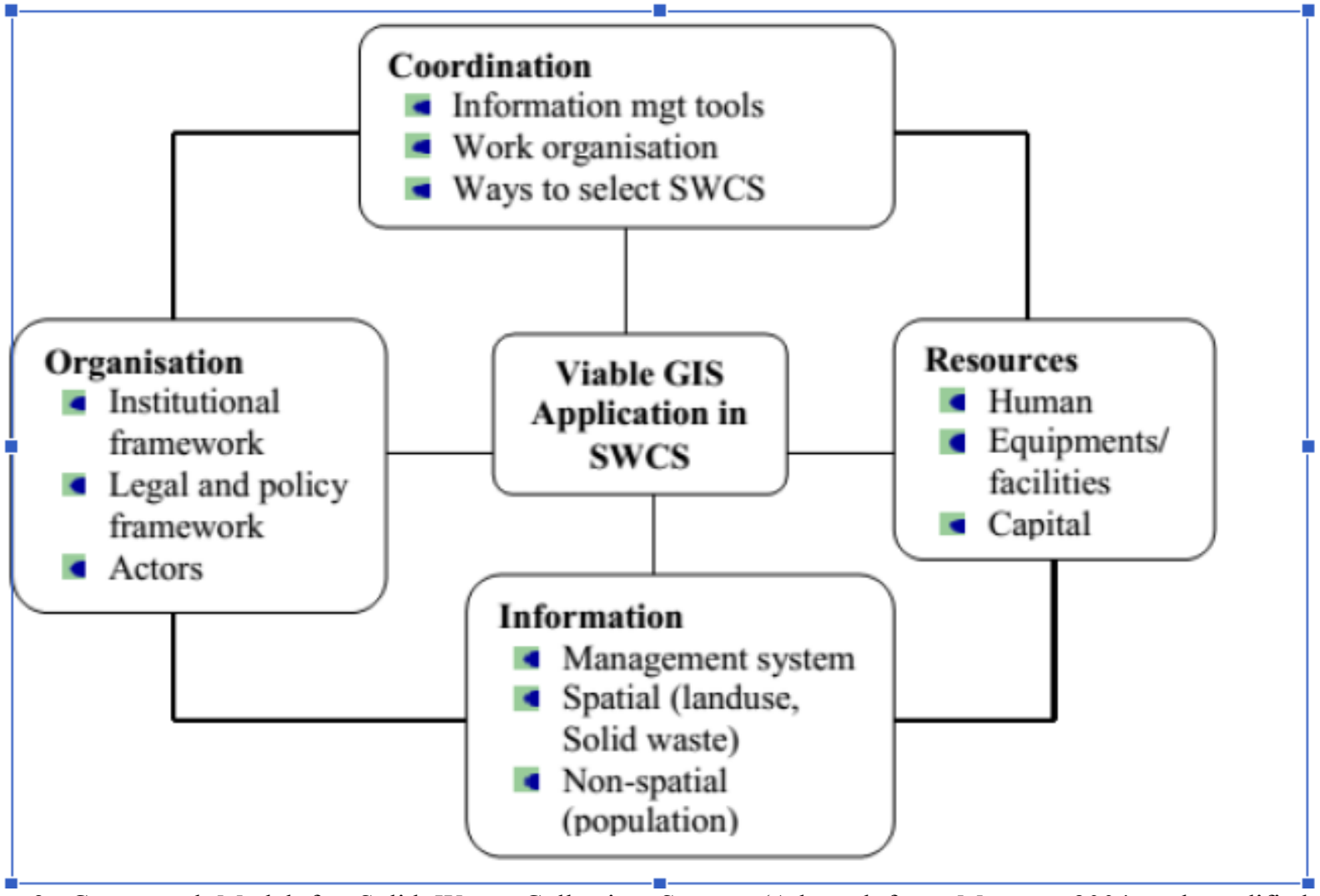

Figure3. Conceptual Model for Solid Waste Collection System (Adopted from Morgan, 2004 and modified by Mwakalinga, 2004)

\section{References}

Abbas, I.I., Nai'ya, R. and Arigbede, Y.A. (2011). Use of remote sensing and GIS in effective and efficient solid management planning: A case study of Samara, Zaria, Nigeria. Res. J. Earth Planet. Stud., 2, 46-52

Allouche, FK., Delaître, E., Ouerchfeni Bousaida, D. \& Chaari, H. (2018). Mapping South Tunisian Landscapes Using Remote Sensing and GIS Applications, International Journal of Environment and Geoinformatics (IJEGEO) 5 (1), 17-28.

Başağaoğlu, H. Çelenk, E., Mariulo, MA. \& Usul, N. (2007), Selection of Waste Disposal Sites Using GIS, Journal of the American Water Resources Association, 33(2), pp 455-464.

Baykal, B. B., Tanik, A., \& Gonenc, I. E. (2003). The impact of watershed land use on maintaining acceptable quality influents for water treatment plants. Journal of Water Supply: Research and Technology - AQUA, 52(8), 587-596.

Chang, N.B, Parvathinathan, G., Breeden, B. J. (2007). Combining GIS with fuzzy multi criteria decisionmaking for landfill siting in a fast growing urban region. J. Environ. Manage, 1(11), 1-15

Direk, Ş., Şeker, DZ., Musaoğlu, N and Gazioğlu, C. (2012). Monitoring and Management of Coastal
Zones Which are Under Flooding Risk with Remote Sensing and GIS, AGU, Fall Meeting 2012. 1596.

E Tinmaz \& I. Demir, 2005. Research on solid waste management systems: To improve existing situation in Çorlu Town of Turkey. In: Science Direct, June 2005

Ghose, M.K., Dikshit, A.K., and Sharma, S.K., (2006). A GIS based transportation model for solid waste disposal- A case studyon Asansol municipality. Journal of Waste Management, 26:1287-1293.

Goodchild, M.F., M.J. Egenhofer, R. Fegeas, and C.A. Kottman, editors (1999). Interoperating Geographic Information Systems. Boston: Kluwer Academic Publishers.

Goumehei, E., Geravandi, Y. \& Yan, W. (2016). A GISBased Study to Investigate Effect of Water Table Changes on DRASTIC Model: A Case Study of Kermanshah, Iran, International Journal of Environment and Geoinformatics (IJEGEO) 3 (2), 110

Gürel, M., Iskender, G., Ovez, S., Arslan-Alaton, I., Tanik, A., \& Orhon, D. (2007). A global overview of treated wastewater guidelines and standards for agricultural reuse. Fresenius Environmental Bulletin, 16(6), 590-595. 
Khajuria, A., Matsui, T. and Machimura, T. (2011). GIS application for estimating the status of municipal solid waste management system: case study of Chandigarh city, India. Our Nature, 9, 26-33

Kironde, J.M. Lusugga (2000). "Rapid Urbanization in Tanzania: The Government's Coping Strategies." In Ngware, S. \& L. Kironde (eds.): Urbanising Tanzania: Issues, Initiatives and Priorities. DUP Ltd. 1996, Dar es Salaam

Menegho, E. (2019). Locational Analysis of Surface Water Quality, Sediment and Dredge Spoil At Nembe, Bayelsa State, NG, International Journal of Environment and Geoinformatics (IJEGEO), 6(1): 15-21. doi: 10.30897/ijegeo.464593

Mohammedshum, A. A., Gebresilassiea, M. A., Rulindaa,C. M., Kahsaya, G. H., Tesfay, M. S.,(2014). Application of GIS and Remote Sensing in effective solid waste disposal site selection in Wukro town, Tigray, Ethiopia. The Int. Arch. Photogram. Rem. Sens. Spatial Inform. Sci., 2, 115-119.

Mohammedshum, AA., Gebresilassie, MA., Rulinda, CM., Kahsay, GH. \& Tesfay, MS. (2014). Application of Geographic Information System and Remotesensing in Effective Solid Waste Disposal Sites Selection In Wukro Town, Tigray, Ethiopia, The International Archives of the Photogrammetry, Remote Sensing and Spatial Information Sciences, Volume XL-2, 2014 ISPRS Technical Commission II Symposium, 6 - 8 October 2014, Toronto, Canada

Moiz, A. S. (2006), Using GIS in Solid Waste Management Planning: A Case of Aurangabad, India, Linköping University Press

Nishanth, T., Prakash, M.N. and Vijith, H. (2010). Suitable site determination for urban solid waste disposal using GIS and Remote sensing techniques in Kottayam Municipality, India. Int. J. Geomatics Geosci., 1(2),19-209.

Rafiu, A.J., Yusuf, O:A., Christopher, OA. \& Maoo, NB. (2018). Spatio-Temporal Urban Expansion Analysis in a Growing City of Oyo Town, Oyo State, Nigeria Using Remote Sensing And Geographic Information System (GIS) Tools, International Journal of Environment and Geoinformatics (IJEGEO) 5(2):104-113.

Rahman, S. H. and Rahman, S. (2009). Urban solid waste management using GIS technique: A case study on Mohammadpur Thana at Dhaka of Bangladesh. Proceedings of the International Conference on Solid Waste Management Technical, Environmental and Socio-economical Contexts WasteSafe 2009, 9 to 10 November 2009, Khulna, Bangladesh, 239-248.

Ramachandra, T. V. and Saira, V. K. (2003). Exploring possibilities of achieving sustainability in solid waste management. Indian J. Environ. Heal, 45(4), 255-64.

Şeker DZ, Goksel C, Kabdasli S, Musaoglu N. \& Kaya S. (2013). Investigation of coastal morphological changes due to river basin characteristics by means of remote sensing and GIS techniques. Water Science Technology, 142.

Senthil S, (2002). GIS-MIS-GPS for solid waste management. In: Map India 2002
Sharholy, M., K. Ahmad, R.C. Vaishya and R.D. Gupta 2007. Municipal solid waste characteristics and management in Allahabad, India. Waste Manage, 27, 490496

Sumathi, R.V., Natesan, U., Sarkar, C. (2008). GIS based approach for optimized siting of municipal solid waste landfill. Waste Manage., 28, 2146-2160.

United Nation s Development Programme (UNDP) (2004). Municipal Solid Waste Management in Developing Countries: A policy Framework. Geneva. Technical 12, Geneva.

Wilson, B.G. and Vincent, J.K. (2008). Estimating waste transfer station delays using GPS. Waste Manage, 28, 1742-1750.

Yomralığlu, T. (2000). Geographical Information Systems Basic Concepts and Applications (In Turkish). Seçil Ofset, Trabzon. 